University of Rhode Island

DigitalCommons@URI

The Rhode Island Current Conditions Index

Economics

$10-2009$

\title{
Rhode Island Current Conditions Index - October 2009
}

Leonard Lardaro

University of Rhode Island, lardaro@uri.edu

Follow this and additional works at: https://digitalcommons.uri.edu/ricci

Part of the Econometrics Commons

Terms of Use

All rights reserved under copyright.

\section{Recommended Citation}

Lardaro, Leonard, "Rhode Island Current Conditions Index - October 2009" (2009). The Rhode Island Current Conditions Index. Paper 46.

https://digitalcommons.uri.edu/ricci/46

This Article is brought to you for free and open access by the Economics at DigitalCommons@URI. It has been accepted for inclusion in The Rhode Island Current Conditions Index by an authorized administrator of DigitalCommons@URI.For more information, please contact digitalcommons-group@uri.edu. 


\section{GURRENT}
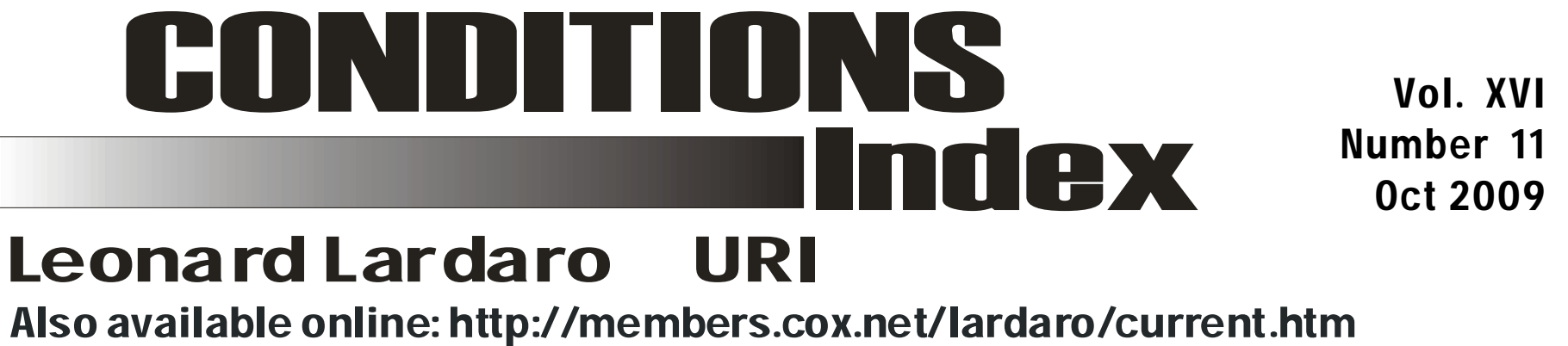

Rhode Island's newly found economic momentum continued in October. For the sixth consecutive month, the Current Conditions Index beat its year-earlier value. The $\mathrm{CCl}$ rose from 33 in September to 42 for October, as five of its twelve indicators improved. And, for the first time since our state's economy regained its pulse, ten of the twelve $\mathrm{CCl}$ indicators either improved relative to their values in September or were virtually unchanged. Clearly, this recession has now evolved from what we witnessed in 2008, the "recession from hell," into a more traditional recession. Hopefully, in the first part of 2010, Rhode Island will begin a recovery, where $\mathrm{CCl}$ values above 50 occur on a regular basis, indicating that more than half of the indicators are routinely improving.

Focusing on the October $\mathrm{CCl}$ performance, there were five improving indicators, four of which displayed healthy changes. US Consumer Sentiment, our "star" performer of late, rose again in October, this time by 22.3 percent, its seventh

\begin{tabular}{|l|r|}
\hline \multicolumn{2}{|c|}{ CCI Indicators - \% Change } \\
\hline Government Employment & -1.6 \\
\hline US Consumer Sentiment & $22.3 \mathbf{~ Y}$ \\
\hline Single-Unit Permits & $3.8 \mathbf{Y}$ \\
\hline Retail Sales & -6.2 \\
Employment Services J obs & -10.5 \\
\hline Priv. Serv-Prod Employment & -3.5 \\
\hline Total Manufacturing Hours & -12.0 \\
\hline Manufacturing Wage & 2.9 Y \\
\hline Labor Force & $0.6 \mathbf{Y}$ \\
Benefit Exhaustions & 68.7 \\
New Claims & -0.05 Y \\
\hline Unemployment Rate & 46.6 \\
\hline \multicolumn{2}{|c|}{ Y = I mproved Value } \\
\hline
\end{tabular}

consecutive year-over-year improvement. Our state's Labor Force continued its recent growth, increasing by another 0.6 percent compared to a year ago. This occurred after a period in which annualized growth rates in excess of 6 percent moved our Labor Force to levels just short of their peak during the last recovery. This has been part of the "fuel" behind the meteoric rise in our state's Unemployment Rate which actually fell slightly in October, from 13 percent to 12.9 percent. Growth in the Manufacturing Wage accelerated in October, rising to a 2.9 percent rate compared to a year ago, its most rapid rate of increase since July. The other two improving indicators are both leading indicators. Single-Unit Permits, which measures new home construction, rose by 3.8 percent in October. While this sounds like good news, it reflects that fact that the 71 permits for the entire state in October bettered the value of 68 from last October. Clearly, new home construction here remains virtually non-existent. New Claims, which reflect layoffs, continued to improve, albeit almost imperceptibly, falling by 0.1 percent compared to last October. The good news was that this indicator remained virtually unchanged from its value last month.

Once again, there were a number of negatives this month. Retail Sales fell by 6.2 percent in October, the latest in a string of consecutive declines that extends all the way back to April of 2008. Future job prospects based on Employment Service Jobs, another leading indicator, remained discouraging, as these fell 10.5 percent compared to a year ago. In spite of this decline, this indicator appears to have stabilized on a monthly basis. Total Manufacturing Hours fell again at double-digit rates, declining by 12 percent in October, as both employment and the workweek fell. Rhode Island manufacturing thus continues to weaken relative to manufacturing nationally. Private Service-Producing Employment fell again at a rate in excess of 3 percent (by $3.5 \%)$, reflecting the grim job prospects here. Government Employment, driven largely by budget woes, declined by 1.6 percent. Ironically October was the second month for which this rate of decline actually moderated. Finally, Benefit Exhaustions, which reflects long-term unemployment, surged again in October, this time by just under 69 percent.

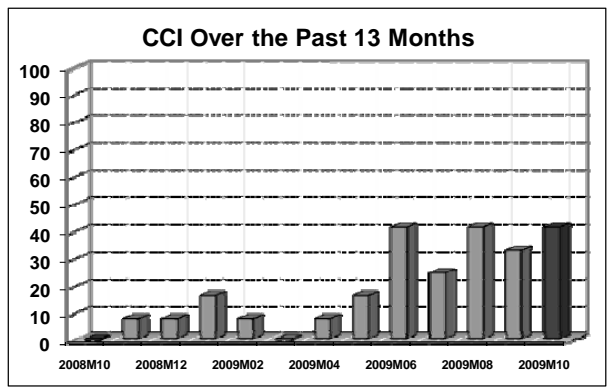

\section{THE BOTTOM LINE}

While Rhode Island remains mired in a recession, it is at long last becoming possible to visualize the end of this recession, hopefully in the first quarter of next year. But when that recovery begins, the pace of economic activity here will be grudgingly slow, as "recovery" will initially designate little more than the fact that the level of economic activity here will no longer be declining.

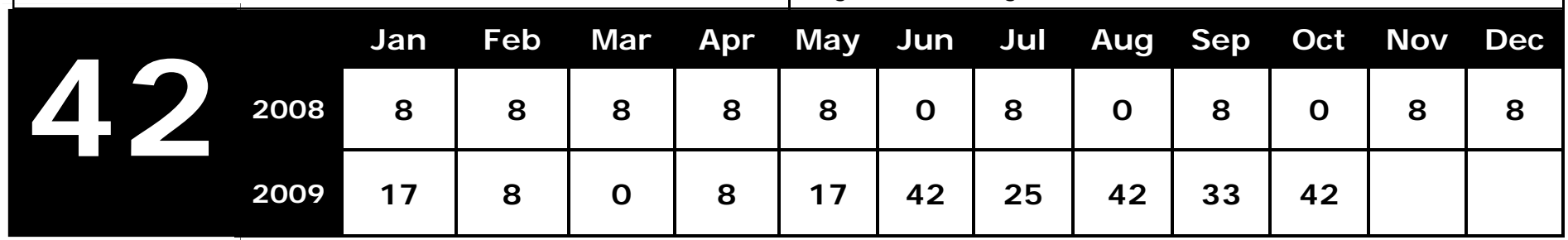

